\title{
Historická slavistika na stránkách sta ročníků Slovanského přehledu. Tradice - současnost - perspektivy
}

\author{
Radomír Vlček (Brno)
}

\begin{abstract}
Abstrakt
Cílem příspěvku je pojednat o historické slavistice jako o jedné z části multioborově pojaté slavistiky. Úkolem je přibližit její tematické i metodologické proměny prostřednictvím statí a článků, které byly publikovány ve sto ročnících periodika Slovanský přehled, tedy mezi léty 1898 a 2014. Práce má analytický charakter s aspirací vyzdvihnout současné trendy v oblasti historické slavistiky a naznačit některé perspektivy. Výchozím bodem je úvodní určení zakladatele Slovanského přehledu sorabisty Adolfa Černého, aby byl Slovanský přehled časopisem, který by naplňoval cíl „sledování rozvoje slovanských literatur, slovanské vědy, umění a vůbec snah kulturních“. Historická slavistika je ve studii sledována především v dimenzi dějin slovanské vzájemnosti, proměn idejí slovanství a vztahů mezi slovanskými národy. Dějiny slavistiky jsou zmíněny jen okrajově, nebot’ podle našeho názoru ve své podstatě tvoří samostatný slavistický obor.
\end{abstract}

\section{Klíčová slova}

Slovanský přehled; dějiny vědy; slavistika; historická slavistika; dějiny slavistiky

\section{Abstract \\ Historical Slavic Studies on the Pages of the Slavonic Review: Tradition - Contemporaneity - Perspectives}

The paper aims to approach historical Slavonic studies as one part of multidisciplinarily conceived Slavonic studies. The aim is to shed light on its thematic and methodological transformations through essays and articles published in 100 issues of the Slavonic Review journal between 1898 and 2014. The work is of analytical nature with the aspiration to highlight the current trends in the area of historical Slavonic studies and suggest some perspectives. The starting point is the initial determination of the founder of Slavonic Review, Sorbian scholar Adolf Černý, to make Slavonic Review a journal meeting the aim of "monitoring the development of Slavonic literatures, Slavonic science, art and generally cultural efforts". Historical Slavonic studies are monitored in the study mainly in the dimension of history of Slavic reciprocity, changes in the ideas of Slavonic patriotism, and relations between

1 Studie čerpá z práce téhož autora, která byla zpracována pro jubilejní svazek Slovanského přehledu. Klade však uvedené údaje do širších souvislostí a upozorňuje na problémy, které s klesajícím institucionálním zajištěním historicko-slavistického studia vznikají. Srov. VLČEK, Radomír: Slovanský přehled a historická slavistika. Slovanský přehled 101, 2015, s. 593-617. 
Slavonic nations. The history of Slavonic studies are mentioned only marginally as they constitute, in our view, an independent field of Slavonic studies.

\section{Key words}

Slavonic Review; history of science; Slavonic studies; historical Slavonic studies; history of Slavonic studies

Slavistice jako víceoborové disciplíně dominovalo po celé 20. století jazykovědné pojetí. Nikdy však nepřestala být její součástí historie. Pro tu část slavistiky, která se věnovala a doposud stále ještě věnuje dějinám, se v českém slavistickém prostoru většinou používá paradigma historická slavistika. Ujalo se zásluhou pražských historiků - slavistů v šedesátých letech 20. století. Jeho užívání ovšem nebylo obecným konsensem. Např. významný moravský historik prof. Josef Macůrek, zakladatel studia dějin střední, východní a jihovýchodní Evropy na Masarykově univerzitě v Brně jej nikdy nepoužíval. Činil tak proto, aby se bránil tendenčnímu vydělování slovanského prostoru z obecných dějin. Pro Macůrka byly dějiny střední, východní, jihovýchodní Evropy součástí obecných dějin a tudíž slovanský prostor součástí většího, obecnějšího celku. Historie byla pro něj pro slavistiku cenná jen ve smyslu dějin slavistiky. ${ }^{2}$

Historické slavistice ovšem nejde jen o dějiny slavistiky, stejně jako jí nejde jen o studium dějin slovanství. Jde jí o historické souvislosti široce pojatého výzkumu slovanských komunit a slovanského prostředí. Tedy o slavistický výzkum založený na historických pramenech a prováděný historickými metodami. V tomto vymezení se ovšem historická slavistika dělí na dva tematické proudy. Prvním je studium slovanství a vztahů mezi slovanskými národy v širokých historicko-kulturologických souvislostech a druhým studium dějin tohoto oboru, tedy dějiny slavistiky. Záběr dějin slavistiky se přitom dotýká dalších slavistických disciplín. Ponechme jej proto nyní stranou a soustřed’me se výhradně na studium slovanství a vztahů mezi slovanskými národy v širokých historicko-kulturologických souvislostech.

V úvodu připomeňme, že studium slovanství a vztahů mezi slovanskými národy navázalo na tradice českého kritického pohledu na slovanství vytvořené Josefem Dobrovským a jeho pokračovateli v 19. století a upevňované ve dvacátých a třicátých letech 20. století, tedy v meziválečném Československu. ${ }^{3}$ Tato tradice byla přerušena druhou světovou válkou a politickými změnami v roce 1948. Diskuse českých historických slavistů, otevřeně čelících zvláště ve druhé polovině šedesátých let 20. století v českém prostředí i na mezinárodním poli sovětskému dogmatismu, však ukázaly, že tradice českého kritického pohledu na slovanství měla pevnou základnu. ${ }^{4}$ Ani po roce 1969 se nepodařilo tento historicko-kritický trend zcela zvrátit a historické slavisty kriticky uvažující o slovanských

2 Srov. VLČEK, Radomír: Josef Macuirek. Praha: Středisko společenských činností AV ČR pro Historický ústav AV ČR, 2015.

3 Srov. MACŮREK, Josef: Misto Slovanů a východni Evropy v obecných dějinách. Slovanský přehled 51, 1965, s. 349-354.

4 Srov. Československé přednášky pro VI. mezinárodni sjezd slavistů. Praha: Academia, 1968. 
souvislostech zcela umlčet. Samizdatová vydání doma a výsledky práce českých historiků v emigraci jsou toho výmluvným důkazem.

V oficiálně tolerované rovině uvnitř Československa se ale v sedmdesátých a osmdesátých letech 20. století mohlo pracovat pouze na některých tzv. vztahových tématech a v započaté práci na dějinách slavistiky. ${ }^{5}$ Docházelo sice $\mathrm{k}$ individuálním polemikám se sovětskými autory, nebylo však myslitelné, aby toto studium oficiálně překročilo dobové meze, či dokonce aby sledovalo jiné než pouze „slovanské“ souvislosti. Přesto toto studium nebylo bezvýznamné. Česká historická slavistika prokázala na řadě mezinárodních setkání, např. mezinárodních sjezdech slavistů schopnost kritické práce doplňující a rozvíjející na jedné straně slavistická studia v jazykovědném smyslu a na druhé straně pouze na historii orientované rozbory. Ve vztahu $\mathrm{k}$ historii by bylo dokonce možné hovořit o jakémsi suplování obecných, tedy světových dějin, nebot dějiny západní Evropy a mimoevropského prostředí byly politickými zásahy značně marginalizovány. ${ }^{6}$

Možnosti české historické slavistiky byly dány institucionální základnou vytvořenou v meziválečném období. Tehdy ji tvořily slovanské semináře na pražské a brněnské univerzitě a Slovanský ústav. Především zásluhou historiků Jaroslava Bidla, Milady Paulové a Josefa Macůrka se vedle jazykovědného a literárního pojetí v meziválečné době rozvíjela ucelená koncepce historicko-slavistického studia. Nešlo o izolované sebestředné studium. Opět se lze odvolat na J. Macůrka, který vždy akcentoval slovanství jako organickou součást vědomí společnosti, vědomí ovlivňované různými kulturně civilizačními souvislostmi. $^{7}$

Po roce 1948 byl však politickým zájmům podřízen nejen výběr slavistických témat, ale i organizační struktura institucí, zabývajících se historickou slavistikou. V roce 1964 byl např. Slovanský ústav ČSAV zrušen. V nově založeném Ústavu dějin evropských socialistických zemí (ÚDESZ) ČSAV (od roku 1968 Ústavu dějin východní Evropy), měla prioritu tzv. politicky aktuální témata. V duchu sovětského pojetí se skutečná slovanská problematika dostávala na okraj zájmu.

Ještě horší situace nastala za tzv. normalizace. V roce 1970 byl z politických důvodů rozhodnutím předsednictva ÚV KSČ zrušen Ústav dějin východní Evropy ČSAV. Ǩada odborníků v něm doposud pracujících byla zbavena zaměstnání a zásadní kritický pohled na slovanskou tematiku nebyl více tolerován. Historicko-slavistická témata ale ani za této situace nezašla na úbytě. Pěstovala se dále, zejména v brněnské pobočce nově zřízeného Československo-sovětského institutu ČSAV. Její slavisticky orientovaní pracovníci mj. vybudovali velmi cennou databázi pro studium dějin slavistiky a intenzívně spolupracovali s kolegy na brněnské filozofické fakultě při studiu dějin vztahů mezi slovanskými národy.

5 Např. Češi a Jihoslované v minulosti. Od nejstaršich dob do roku 1918. Vedoucí autorského kolektivu Václav ŽÁČEK. Praha: Academia, 1975.

6 Srov. KUDĚLKA, Milan - ŠIMEČEK, Zdeněk a kol.: Československé práce o jazyce, dějinách a kultuře slovanských národů od r. 1760. Biograficko-bibliografický slovník. Praha: SPN, 1972; KUDĚLKA Milan - ŠIMEČEK, Zdeněk - ŠŤASTNÝ, Vladislav - VEČERKA, Radoslav: Československá slavistika v letech 1918-1938. Praha: Academia, 1977.

7 Srov. nejnověji: Josepho Macưrek Viginti lustra complenti oblatum. Josef Macuirek a jeho př́nos $k$ dějepisectvi o středni a východni Evropě. Josef Macuirek and his contribution to historiography on Central and East Europe. Ed. Vladimír Goněc. Brno: Masarykova univerzita, 2001. 
Skutečnost tohoto zaměření a této spolupráce se zdála být jedním z důvodů, proč byl v roce 1988 v Brně vytvořen Ústav slavistiky ČSAV. Ve skutečnosti však jeho zřízení sledovalo výhradně administrativní politicky dohlížecí cíle. Na novém pracovišti se totiž sešli vedle několika historiků-slavistů odborníci z poboček společensko-vědních ústavů, kteří měli ke slavistické problematice velmi daleko.

Nekoherentní spojení historiků, etnografů a jazykovědců mělo díky politickým změnám na konci roku 1989 krátké trvání. Na počátku roku 1990 se pracovníci jednotlivých oddělení Ústavu slavistiky ČSAV vrátili do mateřských historických, etnografických a jazykovědných ústavů ČSAV a vytvořili základny pro obnovení jejich brněnských poboček.

Slavistika, sledující historické kořeny a souvislosti však opět našla svoje místo. Od února 1990 se úspěšně rozvíjela v podobě studia slovanství a mezislovanských vztahů v obnoveném Ústavu dějin střední a východní Evropy ČSAV; dějiny slavistiky se pak opět staly ve spolupráci s brněnskou filozofickou fakultou doménou jeho brněnské pobočky. ${ }^{8}$

V brněnské pobočce Ústavu dějin střední a východní Evropy ČSAV se od počátku devadesátých let připravovalo završení dlouhodobého projektu, systematicky mapujícího dějiny české slavistiky. Kromě dosavadního pohledu na tzv. východní dějepisectví se začal rozvíjet „západni““ pohled, v nejednom případě korigující či rozvíjející dosavadní poznatky. V roce 1993 však byl Ústav dějin střední a východní Evropy ČSAV včetně jeho brněnské pobočky zrušen. Většina pracovníků zabývajících se dějinami slavistiky z ČSAV, resp. po vzniku samostatné České republiky reorganizované AV ČR, odešla, nebo se začala věnovat jiným tématům.

Některé úkoly historicko-slavistických studií přece jen přejalo oddělení obecných dějin 19. a 20. století Historického ústavu AV ČR. Zvláště citelnou ztrátou ovšem byla skutečnost, že v následujících několika letech došlo k redukci historicko-slavistických pracovišt také na vysokých školách. Bylo třeba omezit historicko-slavistická studia, zejména sevř́it vějíř slavistických témat.

Podívejme se nyní konkrétně na to, jakým způsobem byla historicko-slavistická témata sledována na stránkách jednoho z nejvýznamnějších slavistických časopisů - Slovanského přehledu. Následující řádky mj. ukazují skutečnost, že Slovanský přehled, který vychází již více než sto let, byl od svého počátku časopisem s mimořádně širokým tematickým záměrem. Od počátku bylo zřejmé, že slavistika je v něm pojímána vskutku jako mezioborová záležitost, přičemž historie má v ní nezastupitelné místo.

Adolf Černý, první vydavatel a současně první hlavní redaktor Slovanského přehledu do úvodního článku prvního čísla prvního ročníku jménem redakce mj. napsal: „Jedenáct let po zaniknuti Jelinkova Slovanského sborniku, jehož každý žretel a na néjž zejména slovanští horovatelé a pracovnici u nás stále vzpominaji, vydává se na pout’ Slovanský prehled, veden

8 Srov. ŠIMEČEK, Zdeněk: Rušti a ukrajinšti slavisté v meziválečném Československu. Slovanský přehled 79, 1993, s. 25-37; NEČAS, Ctibor: Josef Macurrek. Praha: Národní knihovna ČR, Slovanská knihovna, 1998; ŠŤASTNÝ, Vladislav: Devadesát let profesora Josefa Macůrka. Slovanský přehled 77, 1991, s. 2-8; týž: Za prof. dr. Josefem Macuirkem. Slovanský přehled 78, 1992, s. 349; VLČEK, Radomír: Slovanská vzájemnost a panslavismus v českém pojetív prvnich letech po druhé světové válce. Slovanské historické studie 23, 1994, s. 219-238. 
podobnými úmysly a podobnou láskou redakce i nakladatelství, s jakými byl kdysi založen Slovanský sbornik. Účlem jeho bude seznamovati čtenářrstvo se životem ostatních kmenů slovanských. Od Slovanského sborniku tím se bude lišiti, že hlavni žretel bude obraceti $k$ současnému vřeni života slovanského, v̌̌imaje si všech otázek slovanské přitomnosti. [...] Máme přesvědčeni, že vzájemnost slovanská, postavená na základě pravdivého vzájemného poznání, bude pevnějši stavbou, než kdyby se opirala o pouhé mlhovité horováni beze všeho základu. “9

$\mathrm{Z}$ uvedeného je zřejmé, že Černému šlo nejen o to, jak dále napsal: „Je to předevšim sledováni rozvoje slovanských literatur, slovanské vědy, uměni a vi̊bec snah kulturnich “, ${ }^{10}$ ale, a to především, o slovanskou vzájemnost, tedy vztahy mezi slovanskými národy, jejich minulost a minulý i současný stav vědy, která se těmito záležitostmi zabývá, tedy slavistiky včetně její historické odnože (historické slavistiky). ${ }^{11}$ Rozdělme si proto následující př́íspěvek na dvě části: na dějiny slovanské vzájemnosti a na dějiny slavistiky jako vědního oboru.

Historicko-slavistický zájem prostupuje téměř všemi ročníky Slovanského přehledu. $\mathrm{V}$ nejstarších ročnících se setkáme především s informacemi o aktuálním dění a o současných vztazích ve slovanském prostoru. Nicméně již na počátku vydávání Slovanského přehledu v něm najdeme také rozbory slovanské vzájemnosti v její historické retrospektivě. Úměrně růstu významu novoslovanství a referování Slovanského přehledu o slovanských sjezdech, které se konaly na počátku 20. století, se pak začaly již před první světovou válkou objevovat práce o minulosti slovanské vzájemnosti a o jejich proměnách působením dějin. Stejně podstatné místo zaujaly stati o osobnostech, které tuto vzájemnost propagovaly a podporovaly.

V meziválečné době se historicko-slavistické sondy staly významnou oporou formující se identity mladého státu. Ke slovanské vzájemnosti a její minulosti se proto ve Slovanském přehledu vyjádřily i některé významné politické osobnosti. Jedním z nich byl Edvard Beneš, který ve Slovanském přehledu publikoval stat Problémy slovanské politiky. Podobně tak později učinil, ovšem z jiných politických pohnutek slovenský komunistický funkcionář Vlado Clementis. ${ }^{12}$

Témata z dějin slovanské vzájemnosti prezentovaná na stránkách dosavadních ročníků Slovanského přehledu lze rozdělit do dvou rovin. V první z nich se jednalo o sledování př́mých vztahů mezi slovanskými národy, analýzu myšlenky slovanské vzájemnosti a identifikaci její proměny. Součástí této roviny byly analýzy názorů osobností a problémů, které se slovanskou vzájemností bezprostředně souvisely. Ve druhé rovině se jednalo o konkrétní bilaterální vztahy, řešené jak mezi slovanskými národy, státy a společnostmi, tak mezi jednotlivci. Z hlediska četnosti upozorněme především na hojné sledování česko-polských vztahů ${ }^{13}$ a např. na opakované analýzy osobností typu ruského literáta

9 Srov. REDAKCE: Slovo úvodní. Slovanský přehled 1, 1898-1899, č. 1, s. 1.

10 Srov. ibidem.

11 Srov. KUDĚLKA, Milan _ ŠIMEČEK, Zdeněk _ ŠŤASTNÝ, Vladislav _ VEČERKA, Radoslav: Česká slavistika od počátku 60. let 19. století do roku 1918. Praha: Historický ústav, 1997, s. 97-98.

12 Srov. BENEŠ, Edvard: Problémy slovanské politiky. Slovanský přehled 17, 1925, č 1, s. 5-19; č. 2, s. 81-89; č. 4, s. 241-249; č. 5-6, s. 321-345. Ibidem 18, 1926, č. 1, s. 1-16; č. 2, s. 81-102 a č. 3-4, s. 169-208.

13 Srov. ČECHOFIL: Př́spěvek k dějinám polsko-české vzájemnosti. Ibidem 1, 1898-1899, č. 9, s. 427-430. 
Vissariona Grigorjeviče Bělinského. ${ }^{14} \mathrm{~V}$ takových pracích šlo ve Slovanském přehledu primárně o připomenutí významné osobnosti slovanského prostředí, představení jejich názorů a zmínění o době a místě, ve kterém působila. Sekundárně ovšem rovněž šlo o vyzdvižení osobnosti důležité pro myšlenku slovanské vzájemnosti jako jednoho z pilířů české (československé) národní identity. Podobně tomu ovšem bylo i v první rovině, kdy rozbory slovanské vzájemnosti tvořily potřebnou součást aktuální otázky formující se národní (kolektivní) identity českého a československého etnika. Ačkoli se tedy na stránkách Slovanského přehledu prakticky po celou dobu jeho vydávání v něm objevovaly konkrétní historické rozbory slovanské vzájemnosti a jevů (osobností) s ní bezprostředně souvisejících, Slovanský přehled zůstával věrný odkazu Adolfa Černého věnovat se především otázkám aktuálního dění. Slovanská vzájemnost byla totiž jak v předválečném, tak meziválečném období velmi důležitou součástí formující se české (československé) komunity a utvářejícího se samostatného československého státu.

Co se týče metodologického hlediska, jednalo se v těchto pracích i v meziválečném období především o formy lingvistického a literárně vědného rozboru. Proč je spojujeme s historickou slavistikou? Protože jejich analýzy byly činěny s ohledem na možnosti přístupu metod, jež jsou vlastní historickým vědám. Zvláště dobře můžeme tuto skutečnost vysledovat $\mathrm{v}$ případě zajímavých příspěvků k dějinám slovanské civilizace, stejně jako o minulé i současné kultuře jednotlivých slovanských národů.

Zdůrazněme ovšem, že české pojetí slavistiky bylo i přes zájem o historický aspekt tradičně orientováno především filologicky. Historie byla dlouhou dobu chápána jako více či méně pomocná věda, stejně jako poněkud stranou stěžejního filologického zaměření stály dějiny slavistického oboru. Proto se také čeští slavisté častěji soustředili na prezentaci slovanské vzájemnosti v rovině jazyka a literatury než historické sondy. Většina takových statí ovšem nebyla zcela prosta historického kontextu. Leckdy se v nich objevilo i využití historické metody bádání. V opačném smyslu, tedy z pohledu skutečné historické slavistiky, pokud se na stránkách Slovanského přehledu objevila, bývalo to častější od šedesátých let 20. století, bylo (a bývá) využití jiných metod než metod vlastního oboru výjimkou. Nelze tedy hovořit o diskriminaci historiků či historické vědy. Ne vždy také platilo, že by pozitivem historicko-slavistických prací prezentovaných na stránkách Slovanského přehledu bylo chápání slovanské vzájemnosti v širokém spektru oborů, zejména kultury, umění a politiky. Tyto kritiky dovnitř historicko-slavistických řad jsou však vyvažovány skutečností, že zejména v posledních desítiletích ve většině historicko-slavistických prací publikovaných na stránkách Slovanského přehledu takový přrístup najdeme (srov. níže uvedené konkrétní př́íklady).

Dodejme, že výše zmíněným trendům české (československé) historické slavistiky odpovídalo nejen zpracování jednotlivých statí, ale i zpráv z odborného života, recenzí a anotací.

Podívejme se nyní na profilující témata historicko-slavistických studií zveřejňovaných na stránkách Slovanského přehledu poněkud konkrétněji. Co se týče nejstarších ročníků Slovanského přehledu, pak z hlediska vlastních dějin slovanské vzájemnosti je třeba ještě

14 Srov. ŠTĚPÁNEK, Karel: K padesátému výroč́ smrti Bělinského. Ibidem 1, 1898-1899, č. 1, s. 10-15a č. 2, s. 79-85. 
jednou upozornit na práce Lubora Niederleho o nejstarších dějinách slovanských národů. ${ }^{15}$ Tentokrát zejména proto, aby bylo zřejmé, že paralelně s takovými pracemi tvořily druhou linii již v nejstarší době vydávání Slovanského přehledu práce s tematikou historických proměn bilaterálních mezislovanských vztahů. Zde se představovali různí autoři. K tomu dodejme, že jistě bylo pozitivní, že vedle statí českých autorů se vcelku často v periodiku objevovaly překlady jinonárodních autorů, především těch, kteří pocházeli právě ze zemí slovanských. ${ }^{16}$

Do linie historické slavistiky zaměřené na dějiny slovanské vzájemnosti lze jistě zařadit i práce týkající se výkladu o proměnách myšlenky slovanské vzájemnosti v jednotlivých konkrétních zemích. ${ }^{17}$ Najdeme zde ovšem i práce, které se vyjádřily k aktuálnímu stavu vztahu mezi slovanskými národy. ${ }^{18}$

Na význam jednotlivých témat prezentovaných na stránkách periodik je třeba nahlížet v širším kontextu. V případě Slovanského přehledu a historické slavistiky je především o to, že pro vlastní dějiny slovanské vzájemnosti byly od počátku vydávání Slovanského přehledu cenné rubriky Dopisy (později Listy) z různých míst slovanského prostoru (Lužice, Polska, Ruska...). Primárně se v nich totiž pojednávalo o aktuálním dění, zmiňovány byly velké i méně významné akce. Leckdy však byly zasazeny do historického kontextu. ${ }^{19}$ Totéž platilo i o statích řazených nejprve do stejné rubriky, jež byly věnované nekrologům významných osobností. I v těchto případech byly z hlediska historické slavistiky cenné především širší souvislosti, např. identifikování př́ínosu konkrétní osobnosti. ${ }^{20}$ Podotkněme, že tyto statě mohou sloužit i jako pramen pro dnešní nepříliš početná historicko-slavistická bádání.

Adolf Černý byl příkladem osobnosti, která určovala profil časopisu i tím, že se na stránkách Slovanského přehledu zamýšlel nad slovanskou otázkou jako celkem a že se snažil seznamovat čtenáře s různými pohledy na ni. ${ }^{21}$ Přínosné navíc bylo, že tak činil nejen v tematickém, ale i metodologickém ohledu. Jedním dechem s tím dodejme, že výhodou především nejstarších ročníků bylo, že v tomto přístupu zračícího se zanícení pro slavistickou věc nebyl osamocen. Pomáhali mu leckdy i zahraniční přispěvovatelé. Vyzdvihněme např. práce předních ruských historiků. I pro moderní bádání se stala podnětnou např. studie Nikolaje Nikolajeviče Novikova o osvobozeneckém hnutí v Rusku. ${ }^{22}$

15 Srov. NIEDERLE, Lubor: O kolébce národa slovanského. Ibidem 2, 1899-1900, č. 1, s. 1-6 a č. 2, s. 72-78.

16 Srov. ILEŠIĆ, František: Českoslovinská vzájemnost v dř́vějších dobách. Ibidem 2, 1899-1900, č. 4, s. 170-174; FRANKO, Ivan: K dějinám česko-rusinské vzájemnosti. Ibidem 3, 1900-1901, č. 4, s. 156-160.

17 Srov. BAUDOUIN de COURTENAY, Jean: Slováci a koruna sv. Štěpána. Ibidem 1, 1898-1898, č. 1, s. 2-9; č. 2, s. 73-78; č. 3, s. 125-129; č. 4, s. 170-176.

18 Srov. HEJRET, Jan: Slovanstvo a jeho vzájemné styky v letech 1914-1924. Slovanský přehled 1914-1924. Sborník statí, dopisů a zpráv ze života slovanského. Praha, 1925, s. 202-212.

19 Srov. ZDZIECHOWSKI, Maryan: Po sjezdě slovanských novinářů v Krakově. Slovanský přehled 2, 1899-1900, č. 2, s. 91-99.

20 Srov. LUŽIČAN, Dopisy z Lužice. Ibidem 1, 1898-1898, č. 1, s. 22-25; RADIĆ, Stěpan: Charakteristika a význam IV. sjezdu slovanských novinářri. Ibidem 4, 1901-1902, č. 9, s. 416-419.

21 Srov. ČERNÝ, Adolf: Nejnovějši úvahy o slovanské otázce. Ibidem 10, 1907-1908, č. 3, s. 113-116; č. 4, s. 168-174; č. 6, s. 257-261 a č. 7, s. 300-307.

22 Srov. NOVIKOV, Nikolaj N.: Panslavismus a osvobozenecké hnutí v Rusku. Ibidem 10, 1907-1908, č. 4, s. 147152. 
Další předností Černého bylo, že neskrýval skutečnost rozporů, které se mezi slovanskými národy a jejich reprezentanty v minulosti i současnosti objevovaly. Zřetelně se k nim vyjádřil např. ve stati motivované zprávou o cestě Karla Kramáře a Ivana Hribara do Petrohradu a Varšavy v souvislosti s př́ípravami slovanského sjezdu v Petrohradě v roce $1908 .{ }^{23} \mathrm{~V}$ roce 1909 pak o dění na slovanském sjezdu zevrubně informoval. Opět včetně zmínek o nesouladu v postojích vůči slovanské otázce. ${ }^{24}$ Podobně pak činil i v dalších svých statích o slovanském sjezdu v Sofii v roce 1910. Opět ve stejném, realistickém a kritickém duchu. Bylo zřejmé, že vědecký široce slavistický pohled včetně historicko-slavistickému př́ístupu mu byl vlastní. ${ }^{25}$

Nelze však nepřipomenout i opačnou stránku, a to, že v této době se ve Slovanském přehledu psalo i o vizích o slovanské vzájemnosti. Tedy, jak by se slovanská vzájemnost mohla či měla v budoucnu rozvíjet, jaké by byly možnosti její institucionalizace a jak by to mohlo vypadat, existoval-li by např. všeslovanský výbor. S tím souvisela více či méně výrazná idealizace, možno říci, romantizace slovanské vzájemnosti a slavistického př́istupu k ní. ${ }^{26}$

Slovanský přehled se od samotného počátku profiloval jako odborný časopis, který bude nezaujatě referovat také o nových knihách, časopisech i jednotlivých statích týkajících se slovanské problematiky. ${ }^{27}$ Nás pochopitelně nejvíce zajímají ty s historicko-slavistickou tematikou. Přiznejme, že ne vždy byla redakce schopna, a to již na svém počátku, toto svoje krédo zcela naplňovat. Kriticky se lze v tomto směru podívat zejména na některé překlady recenzí a zpráv a na tradiční problém užívání zaběhlých paradigmat. Např̀. obsáhlejší článek - recenze Maryana Zdziechowského o díle ruského filozofa Vladimíra Sergejeviče Solovjovova nesla název Vladimír Solovjov a slovanofilstvo. Z obsahu je zřejmé, že autorovi šlo výhradně o slavjanofilství. Zaměřil se totiž výhradně na ruské národní vědomí. Nikoli však tak, aby vysvětlil jeho podstatu, ale pouze okrajově, pro poznání souvislostí. Ve stejně stati najdeme i problém ohledně přiznání rusko-polského konfliktu. Autor o něm hovoří jen neochotně a skrývá jej pod vizi obecného slovanství. Je to ovšem analogie pozdějších statí, kde se většinou slovanofilství zaměňuje za slavjanofilství a slovanofilství se adoruje. ${ }^{28}$

23 Srov. ČERNÝ, Adolf: Po slovanských dnech v Petrohradě a ve Varšavě. Ibidem 10, 1907-1908, č. 10, s. 437-446.

24 Srov. týž: Slovanské sjezdy r. 1908. Ibidem 11, 1908-1909, č. 1, s. 7-15 a č. 2, s. 61-67.

25 Srov. POLÍVKA, Jiří: Slovanský sjezd Sofijský v červenci 1910. Ibidem 13, 1910-1911, č. 3, s. 119-120; GRABOWSKI, Tadeáš Stan.: Ještě slovanský sjezd v Sofii. Ibidem 14, 1911-1912, č. 1, s. 27-32; č. 2, 78-82 a č. 3, s. 119-123.

26 Srov. ZAMOJSKÝ, O.: Hudba budoucnosti... Ibidem 11, 1908-1909, č. 1, s. 19-23; BOHÁČ, Antonín:Volné kapitoly ze statistiky Slovanstva. Ibidem 14, 1911-1912, č. 1, s. 7-11 a č. 2, s. 55-57.

27 Srov. BRUMMER, Alexandr: Jací jsou Slované? České predstavy o slovanské povaze v 19. a proní polovině 20. století. Ibidem 97, 2011, č. 1-2, s. 281-301; týž: Rusko a „naše osvobozeni“. Význam válečného rusofilstvi a vztahu k carskému Rusku za Velké války a v meziválečném obdobi. Ibidem 98 (Slovanské historické studie 37), 2012, č. 5, s. 465-536; týž: Rusko opět „slovanské"? České rusofilstvi a pozitivni obraz Sovětského svazu v poslednich letech proni republiky. Ibidem 99 (Slovanské historické studie 38), 2013, č. 5, s. 499-532.

28 Srov. ZDZIECHOWSKI, Maryan: Vladimír Solovjov a slovanfilstvo. Ibidem 3, 1900-1901, č. 7, s. 303-310 a č. 8 , s. 371-378. 
Zásadní změnu v tematice i metodologickém zpracování historické slavistiky přinesla druhá světová válka a období, které po ní bezprostředně následovalo. Válka přirozeně vedla $\mathrm{k}$ požadavku míru. Jeho udržení a upevnění se stalo každodenní součástí poválečného života. Noviny a četná periodika je mimořádně akcentovaly. Nejinak tomu bylo i ve Slovanském přehledu. Obvyklými se proto v něm staly statě typu Slované a mír. ${ }^{29}$

Před únorem 1948 bylo ovšem pozitivní, že rostl počet studií věnovaných slovanství z pohledu proměn demokracie ${ }^{30}$ a dokonce i hospodářských vztahů (jejich pozitivního rozvoje) mezi slovanskými národy. ${ }^{31}$ Do roku 1948 se přitom udržela možnost tematických i metodologických diskusí. Leckdy však již této době bylo cílem kouzlo chtěného. Nikoli již kritický rozbor slovanství, ale jeho vyzdvihování (adorace), hledání slovanské holubičí povahy a spojování slovanství s internacionalismem. Pro česká historicko-slavistická studia krátce po druhé světové válce se právě v tomto smyslu stala slovanská tematika mimořádně frekventovanou.

Únorové události roku 1948 přinesly další změnu. Vlastně již ani ne tak změnu, jako zřetelně změněný cíl: Zájem o slovanství vystřídal zájem o proletářský internacionalismus a s ním spojenou adoraci všeho sovětského, nejčastěji revolučního. ${ }^{32}$ Výjimkou nebylo ani apriorní provazování tzv. pokrokových slovanských tradicí s předními tvůrci poúnorového Československa. ${ }^{33}$

Články se skutečnou historicky slovanskou tematikou na několik let stránky Slovanského přehledu opustily. Znovu se mohly objevit až od druhé poloviny padesátých let 20. století. Nejčastěji pak ve formě speciálně sledovaného revolučně orientovaného rusofilství. ${ }^{34}$ Pochopitelně v pozitivním vztahu k ruským revolučním tradicím. Z hlediska tematického ale i metodologického o profilu těchto prací svědčí jejich již zmíněný apriorní důraz na rusofilství, resp. postoj zmíněných osobností k Rusku. Ty, které k Rusku zaujímaly jistý kritický postoj, mohly být publikovány až v uvolněnější atmosféře šedesátých let. Zejména to platilo o slovanofilství a rusofilství prvního československého prezidenta Tomáše G. Masaryka (1850-1937). ${ }^{35}$

29 Srov. DJILAS, Milovan: Boj slovanských národů za mír a demokracii. Ibidem 33, 1947, č. 1-2, s. 6-17; GREKOV, Boris D.: Úloha Slovanů v déjinách světové kultury. Tamtéž 33, 1947, č. 1-2, s. 17-33; NEJEDLÝ, Zdeněk: Slovanské národy v boji za mír. Ibidem 35, 1949, č. 1, s. 4-5; GUNDOROV, Aleksandr S.: Slované bojovali a bojuji za mir. Ibidem 35, 1949, č. 1-2, s. 6-7.

30 Srov. CLEMENTIS, Vlado: Slovanská a demokratická myšlienka u Slovákov. Ibidem 32, 1946, č. 5-6, s. $260-$ 265; ČEJCHAN, Václav: Revolučni slovanstvi M. A. Bakunina. Ibidem 32, 1946, č. 5-6, s. 266-284; KREJČÍ, Karel: Revolučni slovanství polské. Ibidem 32, 1946, č. 7-8, s. 391-396.

31 Srov. GEORGIJEV, Kimon: Slovanská vzájemnost a hospodářské vztahy mezi slovanskými zemèmi. Ibidem 32, 1946, č. 7-8, s. 369-372; MAXA, Prokop: Nová slovanská politika. Ibidem 32, 1946. č. 7-8, s. 372-377.

32 Srov. SLAVÍK, Václav: Československo vděč za svioj vznik Velké Říjnové revoluce. Ibidem 35, 1949, č. 7-8, s. 1-2; PLATKOVSKIJ, Vladimír V.: Mezinárodni význam Řijnové socialistické revoluce. Ibidem 35, 1949, č. 7-8, s. 3-5.

33 Klement Gottwald - tvưrce našeho spojenectvi se Sovětským svazem. Ibidem 35, 1949, č. 7-8, s. 5-6; PROCHÁZKA, Jaromír: Generalissimus Stalin - geniálni vojevioidce př́tomnosti. Ibidem 35, 1949, č. 9-10, s. 7-10.

34 Srov. ČEJCHAN, Václav: Karel Havličék Borouský a Slované. Ibidem 42, 1956, č. 6, s. 186-188.

35 Srov. SLÁDEK, Zdeněk: T. G. Masaryk a revolučni Rusko. Ibidem 54, 1968, č. 6, s. 462-469; SYLLABA, Theodor: K problematice vztahu T. G. Masaryka k Říjnové revoluci. Ibidem 54, 1968, č. 5, s. 386-391; NOVÝ, 
Ideologická dominance tzv. proletářského internacionalismu v první polovině padesátých let 20. století bránila zmínkám o slovanství jako o podstatné součásti české národní identifikace. Ve druhé polovině padesátých let se podařilo tuto bariéru alespoň zčásti prorazit. ${ }^{36}$ Novým prvkem, který se ve druhé polovině padesátých let objevil a měl pozitivní dopad na profilování historicko-slavistických statí publikovaných ve Slovanském přehledu, bylo seznamování se se slavistickou prací na různých československých i zahraničních (v drtivé míře však pouze tzv. východních) pracovištích. ${ }^{37}$ Toto zaměření zintenzivnilo ve Slovanském přehledu v souvislosti s blížícím se sjezdem slavistů v Moskvě v roce $1960 .^{38} \mathrm{~K}$ dobru věci po jeho skončení neodeznělo. Stalo se součástí politického uvolnění šedesátých let 20. století, které umožnilo československým společenskovědním badatelům lepší přístup k zahraniční (i západní) literatuře.

Pro rozvoj oboru historické slavistiky se stala významnou stat’ Miroslava Bidlase, která souvisela s př́ípravami sjezdu slavistů v Moskvě. Autor v odkazu na mezinárodní jednání totiž zřetelně prokázal, že historie může být ve slavistice filologii rovnocenným partnerem. Ukázal, že využitím historie lze zasadit jazykovědné slavistické pojetí do širších historických souvislostí. Bidlas historické přístupy neadoroval. Nechtěl jimi nahradit filologické metody. Šlo mu o to dokázat, že historie může i filologicky pojaté slavistice pomoci v jejím poznání, a tím prospět slavistice jako oboru k prohloubení znalostí ve smyslu, dnes bychom řekli v intencích brněnské slavistické školy, areálových studií. ${ }^{39}$

I když to patrně nebylo Bidlasovým cílem, jako by jeho práce předjímala diskusi o vymezení slavistiky, která se v českém prostředí rozvinula o deset let později. Ta se ovšem odehrávala v jiné politické atmosféře. V té se také objevila snaha přehodnotit internacionální pojetí rusofilství, které bylo interpretováno v první polovině padesátých let a ukázat jeho skutečný obraz v tradicích kritického českého rusofilství ${ }^{40} \mathrm{Z}$ tohoto pohledu začali věnovat rusofilství pozornost zejména Zdeněk Sládek ${ }^{41}$, Milan Švankmajer ${ }^{42}$ a Vladimír Hostička, tedy nová generace historických slavistů. ${ }^{43}$ Měli výhodu v tom, že se na stránkách Slovanského přehledu začaly objevovat edice a drobnější pramenné přríspěvky. Jiný přístup $\mathrm{k}$ pramenům byl totiž stále ještě velmi obtížný. ${ }^{44} \mathrm{Z}$ tohoto hlediska nelze při iden-

Lubomír: Fenomén Ruska v Masarykově filozofii. Ibidem 55, 1969, č. 3, s. 201-208; ŠŤASTNÝ, Vladislav: Masaryk a české rusofilstvi. Ibidem 55, 1969, č. 2, s. 134-139.

36 Srov. KEPKA, Rudolf: V zásvitu velké ideje (Slovanstvi oporou a posilou českého národního obrození). Ibidem 39, 1953, č. 8, s. 249-251 a č. 9, s. 287-289.

37 Srov. KRYSTÝNEK, Jiří: Studium slavistiky na filosofické fakultě v Brně. Ibidem 41, 1955, č. 3, s. 109-110; STANISLAV, Ján: Vývoj slavistických štúdii na univerzitě v Bratislavě. Ibidem 41, 1955, č. 6, s. 215-216.

38 STANISLAV, Ján: Slovenská slavistika v rokoch 1945-1960. Ibidem 46, 1960, č. 4, s. 201-204; DOLANSKÝ, Julius: Studium slovanských literatur u nás od roku 1945. Ibidem 46, 1960, č. 1-2, s. 260-268.

39 Srov. BIDLAS, Miroslav: Palacký, Havlíček a Zap k některým otázkám dějin východních Slovanů. Ibidem 47, 1956, č. 10, s. 351-352.

40 Srov. ŠVERMA, Jan: Slovanská myšlenka v české politice. Ibidem 35, 1949, č. 7-8, s. 52-53.

41 Srov. SLÁDEK, Zdeněk: Rusofilstvi včera a dnes. Ibidem 49, 1963, č. 5, s. 238-241.

42 Srov. ŠVANKMAJER, Milan: Ještě k otázce českého rusofilstvi. Ibidem 50, 1964, č. 1, s. 23-25.

43 Srov. HOSTIČKA, Vladimír: Počátky Hankova rusofilství. Ibidem 50, 1964, č. 6, s. 346-355.

44 Srov. VRBA, Přemysl: Neznámé policejni dokumenty k rusofilské činnosti Leoše Janáčka. Ibidem 49, 1963, č. 1, s. 19-21. 
tifikování vývoje historické slavistiky ponechat bez povšimnutí na stránkách Slovanského přehledu publikované pramenně přínosné práce ruských historiků. ${ }^{45} \mathrm{~K}$ nim pak jistý pendant tvořily příspěvky sledující význam bohemikálních dějinných událostí pro širší slovanské prostředí a slovanskou vzájemnost. ${ }^{46}$

Počátek normalizace, podobně jako i v jiných vědních oborech, pozitivní trendy druhé poloviny šedesátých let 20. století zastavil. Historická slavistika měla výhodu v jisté nepolitičnosti svých zaměření. Za normalizace proto mohlo alespoň zčásti zpracování témat z dějin mezislovanských vztahů a slovanské vzájemnosti pokračovat. ${ }^{47}$ Znovu mohlo být sledováno i obecné slovanství. Jednalo se však o ojedinělou záležitost. Vyzdvihněme proto ty, kteří v ní v sedmdesátých letech vynikli, a to brněnští historičtí slavisté Lubomír Havlík, Zdeněk Šimeček, Milan Kudělka a Vladislav Štastný.

Po roce 1970 opět poklesla možnost získat zahraniční literaturu a vycestovat do zahraničí. Práce sovětských autorů, zejména těch, které jsme výše uvedli, přinášely kromě vlastního rozboru i edice dokumentů. Jinými cestami by se k nim čeští autoři dostávali jen stěží. Zvláště cenný byl tento fakt pro novou generaci historických slavistů, která zahájila svoji vědeckou dráhu v osmdesátých letech. Jak ještě níže uvidíme, umožnila jim tematické rozšíření a inspirovala je k později umožněným novým pramenným bádání v českých i ruských archivech. Ale nešlo jen o osmdesátá léta. Co se týče jednotlivých sledovaných událostí a problémů, na nichž nebo prostřednictvím nichž se rozvíjela myšlenka slovanské vzájemnosti, pak je třeba již od konce šedesátých let upozornit na mimořádně zajímavé historicko-slavistické studie, které byly věnovány slovanskému sjezdu v Praze roku $1848^{48}$ a sjezdům v letech $1866^{49}$ a $1868 .^{50}$

Změnu v pojetí českého slovanství a jeho historicko-slavistickém sledování přinesla osmdesátá léta 20. století. ${ }^{51}$ Autoři se v nich totiž stále více zaměřovali na konkrétní problémy a proměny idejí. Opouštěny byly pohledy na obecné slovanské ideje a zamyšlení nad jejich významem. ${ }^{52}$ Sledování slovanských myšlenkových proudů a inklinace národních prostředí

45 Srov. LAPTĚVOVÁ, Ludmila P.: Vývoj ideje slovanství v Rusku v XIX. a na počátku XX. století. Ibidem 54, 1968, č. 4, s. 304-309.

46 Srov. MIKULKA, Jaromír: Husitstvi a slovanský svět. Ibidem 54, 1968, č. 3, s. 195-201.

47 Srov. BORODOVČÁK, Viktor: Ján Palárik a Slovanstvo. Ibidem 58, 1972, č. 4, s. 266-271.

48 Srov. ŠAMBERGER, Zdeněk: Zmařeni slovanského sjezdu roku 1848. Ibidem 64, 1978, č. 6, s. 454-471.

49 Srov. ŠESTÁK, Miroslav: Vídeňský „slovanský“ sjezd roku 1866. Ibidem 55, 1969, č. 1, s. 27-34.

50 Srov. ŽÁČEK, Václav: Pokusy o slovanské sjezdy po r. 1867. Ibidem 54, 1968, č. 3, s. 202-211.

51 Srov. KOLEJKA, Josef: Bakuninova cesta k nové slovanské politice z roku 1848. Ibidem 73, 1987, č. 5, s. 367-377; týž: Bakuninovo provolání ke Slovanům z prosince 1848 a jeho úsili o společný postup proti Rakousku. Ibidem 74, 1988, č. 2, s. 114-123.

52 Srov. MIKULKA, Jaromír: „Nové slovanské hnuti“ v Polsku. Ibidem 73, 1987, č. 3, s. 177-191 a č. 4, s. 303313; týž: Polské slovanstvi na prelomu 19. a 20. století. Ibidem 68, 1982, č. 1, s. 13-33; týž: Polské slovanstvi v letech mezi dvèma světovými válkami. Ibidem 72, 1986, č. 2, s. 97-106 a č. 4, s. 273-284; týž: Polské slovanstvi za pruni světové války. Tamtéž 71, 1985, č. 1, s. 41-53; týž: Poustáni 1863 a polské slovanství. Tamtéž 69, 1983, č. 2, s. 125-131; ŠESTÁK, Miroslav: České slovanství a austroslavismus do r. 1848. Ibidem 76, 1990, č. 4, s. 263-266; týž: K otázce panslavismu. Ibidem 76, 1990, č. 4, s. 273; IVANTYŠYNOVÁ, Tatiana: Postoj ruských slavianofilov $k$ slovanskej otázke v Rakúsku v prvej polovici šesṫdesiatych rokoch 19. storočia (Úloha novín „Deñ “ a ich vydavatel'a a redaktora I. S. Aksakova). Ibidem 59, 1973, č. 4, s. 274-280; VLČEK, Radomír: M. P. Pogodin a formováni ruského panslavismu. Ibidem 81, 1995, č. 3, s. 193-209. 
ke slovanstvím zůstalo zachováno a dokonce se i rozvíjelo. ${ }^{53}$ Například tím, když se formování slovanství ve vztahu k českému národnímu vědomí nově věnovali na počátku 21. století i mladí historici. A cenné bylo i to, že z hlediska metodologie byla v těchto případových studiích užita široká komparace navazující na analýzu problému. ${ }^{54}$ Celkově však téma slovanské vzájemnosti po sametové revoluci začalo ze stránek Slovanského přehledu mizet. Souviselo to ovšem s tematickým a metodologickým posunem, v němž bylo konkrétně historické studium založeno na pramenech a mnohdy i na psychoanalytických prožitcích jednotlivců. Nová dimenze otázky slovanské vzájemnosti se ale do časopisu nedostala.

Historická slavistika byla tedy tradičně v českém prostředí pojímána jako obor stojící na pomezí dějepisectví a slavistiky. V dnešní době vyžadující interdisciplinární pohledy na problémy, má jistě co říci. Přesto jí ani v rámci dějepisectví ani v rámci slavistiky není věnována pozornost, noví specialisté téměř nejsou vychováváni. To se negativně odráží i na stránkách Slovanského přehledu. Pružnější je v tomto směru politologie, která, jak ostatně plyne i z uvedených témat prezentovaných v posledních ročnících Slovanského přehledu, má ve své slavistické větvi více jasno. Jaké jsou tedy perspektivy? Věřme, že optimistické. Na půdě Historického ústavu Akademie věd ČR, ale při silném zastoupení historických slavistů filozofických fakult Masarykovy univerzity, Karlovy univerzity a Palackého univerzity, v úzké spolupráci s historickými slavistiky a politology dalších předních českých, ale i slovenských a polských vysokých škol, bylo v roce 2015 ustaveno Výzkumné centrum pro dějiny východní Evropy. Jeho náplní je jen výsek historicky-slavistické tematiky. Ale i tento výsek podpořený institucionálně skýtá optimismus, že historická slavistika bude v českém prostoru i nadále pěstována. Mezinárodní charakter centra se pak jistě pozitivně projeví i na metodologii zpracování a studování nových v českém prostředí jen málo zmapovaných témat. ${ }^{55}$

\section{doc. PhDr. Radomír Vlček, CSc.}

Historický ústav AV ČR, pobočka Brno

Veveří 97, 60200 Brno, Česká republika

vlcek@brno.avcr.cz

53 Srov. ŠŤASTNÝ, Vladislav: České rusofilství v 70. a 80. letech 19. stol. Ibidem 76, 1990, č. 1, s. 2-8; VLČEK, Radomír: Nacionalismus, panslavismus a neoslavismus - pokusy o řě́ení krize ruského impéria na přelomu 19. a 20. stoleti? Ibidem 80, 1994, č. 1, s. 1-17; BEDNÁROVÁ, Marcela: Slovanský mýtus v reflexi chorvátskeho ilyrismu. Ibidem 80, 1994, č. 4, s. 523-537.

54 Srov. BRUMMER, A.: Jací jsou Slované, s. 281-301; týž: Rusko a „naše osvobozeni“, s. 465-536; týž: Rusko opět „slovanske“", s. 499-532.

55 Srov. http://www.hiu.cas.cz/cs/organizacni-struktura/vyzkumne-centrum-dejin-vychodni-evropy.ep/. Staženo 7. 12. 2015. 